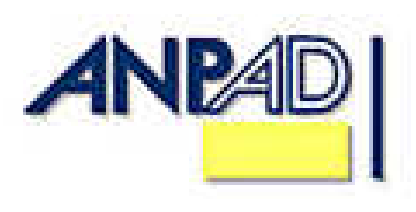

Available online at

http://www.anpad.org.br/bar

\title{
Archetypes of Organizational Success and Failure
}

\author{
Denise L. Fleck * \\ E-mail address: denise@ coppead.ufrj.br \\ Instituto COPPEAD de Administração - Universidade Federal do Rio de Janeiro \\ Rio de Janeiro, RJ, Brazil.
}

\begin{abstract}
This paper presents inductive theoretical work inspired by the empirical study of the high-tech rivals General Electric and Westinghouse. Comparative historical analysis suggests that each firm's responses to five organizational challenges have affected their chances of enjoying long-term success. In addition, the theoretical work advances two polar ideal types of organizational success and failure: the self-perpetuating and the selfdestructive archetypes, respectively. These should be seen as extreme states of the existence of firms since, in reality, firms operate in some intermediary state. A process-oriented perspective of theory building advances relations of necessity towards organizational long-term success, and integrates the responses to challenges into a requisites model for the development of a propensity for organizational self-perpetuation.
\end{abstract}

Key words: organizational archetypes; corporate growth; healthy longevity of organizations; theory building.

Received 21 January 2008; received in revised form 01 December 2008.

Copyright (C) 2009 Brazilian Administration Review. All rights reserved, including rights for translation. Parts of this work may be quoted without prior knowledge on the condition that the source is identified.

* Corresponding author: Denise L. Fleck

Rua Pau Marfim, 25, Rio de Janeiro, RJ, 22753-803, Brazil. 


\section{INTRODUCTION}

The motivation for this study derives from the empirical observation that success seems to breed failure. More often than not, today's widely praised corporate success stories become tomorrow's highly criticized nightmares. The intriguing issue concerning the sustainability of organizational success in the long run has inspired much needed research (Kocka, 1990; Scherer, 1990) into why some positions of industrial dominance are persistently maintained and why early success stories so frequently turn into stories of decline and failure.

This paper addresses these questions by reporting inductive work on twelve decades of existence of two centenarian companies: General Electric [GE], a firm that has persistently maintained positions of industrial dominance and high financial performance, and Westinghouse [WH], an early success story that faced decline and disintegration.

Comparative analysis of the companies' behavior has revealed that throughout their existences GE and WH markedly differed in their responses to five growth-related managerial challenges. Through a process of analytic generalization (Yin, 1989), I have generalized the set of empirical results to a broader theory of organizational long-term success and failure, proposing two ideal organizational types: one archetype of success and one of failure. In addition, I have used a process-oriented perspective of theory building (Mohr, 1982) to put forward relations of necessity among constructs, and derived a model of requisites for the development of organizational long-term success.

\section{THEORETICAL BACKGROUND}

Organizational success is a central issue in organizational studies, and growth is often believed to be an adequate indicator of organizational success. As Whetten (1980) remarked, in general, organizational growth is an implicit assumption in research studies because it is generally assumed that "growth is synonymous with effectiveness", that "bigger is better" and that "there is a positive correlation between size and age" (p. 577). Other definitions of success emphasize the time dimension. For example, according to Miller and Friesen (1978, p. 923), success is related to "the degree to which the firms are able to achieve their objectives subject to the constraints of long run viability". A related notion is organizational self-perpetuation (Chandler, 1977), i.e. the firm's ability to survive its members. On the other hand, the organizational life cycle perspective (Whetten, 1987) predicts that sooner or later, organizations enter the decline phase and face death.

Though much less popular than organizational success (Whetten, 1980, 1987), organizational failure has also been referred to in the literature in different ways. These include: organizational mortality, organizational death, organizational exit, bankruptcy, decline, retrenchment and downsizing (Mellahi \& Wilkinson, 2004). Opposing growth and decline, Whetten (1980) has distinguished two types of decline: decline-as-stagnation referring to suicidal organizations suffering from stagnation and market share reduction, and decline-as-cutback designating organizations that fall victim of a hostile, homicidal environment that undergoes market shrinking. Weitzel and Jonsson (1989) have called into question the validity of both the organizational life cycle and the imperative of the organization's death. These authors view decline as a process that may lead to organizational destruction and have proposed a model of stages of decline progressing from blinded to inaction, faulty action, crisis and dissolution. From a temporal perspective, Meyer and Zucker (1989) have coined the term permanently failing organizations to designate those entities that combine persistence of existence with persistently poor performance.

Empirical studies by Miller and Friesen $(1977,1984)$ have addressed both organizational success and failure. Relating organizational performance to strategy, structure and the environment, these 
authors have induced ten archetypes, six of success and four of failure. From a longitudinal perspective, they have suggested that these archetypes constitute organizational states and that over time organizations may experience a state change within the set of successful or unsuccessful archetypes, or between those two sets.

In line with Weitzel and Jonsson (1989), this paper defines organizational failure as the final state of a decline process, i.e. the state of organizational dissolution. On the other hand, organizational success is not a final, but a potential state that can be approached as long as the organization nurtures a propensity to self-perpetuate (Chandler, 1977). Self-perpetuation has to do with the organization's capacity to outlive its members. Much like the growth process (Penrose, 1980), the self-perpetuation process does not take place automatically. It requires the setting up of contributing mechanisms, such as managerial hierarchy formation (Chandler, 1977, 1990). The setting up of mechanisms implies purposeful actions taken by organizational stakeholders interested in the continued existence of the firm. In addition, a dynamic worldview of firms and environment suggests that self-perpetuation should not be seen as a stable or final state. Rather, organizations are likely to experience a dynamic process whereby the propensity to self-perpetuate may be developed, enhanced, reduced or even precluded. The notion of self-perpetuating organizations is challenged by theoretical conjectures such as whether organizations, by their nature, undergo irreversible processes of decline and entropy, and whether organizational growth reaches an inevitable point of continued diminishing returns (Whetten, 1987). Penrose refutes both conjectures based on a lack of evidence suggesting that organizational death is inevitable (Penrose, 1952) and on the possibility of organizational growth through diversification (Penrose, 1980).

According to Chandler (1977), the self-perpetuating capability of the modern enterprise is the outcome of two concomitant processes: continuing growth, whereby growth brings about new opportunities for expansion and renewal; and continued existence, a process that has to do with the organization's ability to preserve its integrity and avoid becoming an expendable tool (Selznick, 1957).

\section{Continuing Growth}

Chandler's continuing growth notion (1977) is in line with Penrose's work (1980), which states that underutilized resources constitute internal inducements to continuing growth. Both authors describe a renewal mechanism whereby, in order to make efficient use of underutilized resources, new types of resources are generally acquired. While Chandler distinguishes growth motivations, Penrose refers to enterprising services.

Chandler (1977) advances two types of motives guiding expansion decisions: productive and defensive. While productive motives promote change, defensive ones control change. Productive expansion increases "productivity by lowering unit costs" (p. 487). Defensive expansion seeks security and aims "to prevent sources of supplies or outlets for goods and services from being cut off or to limit entry of new competitors into the trade" (p. 486). In Chandler's analysis, defensive expansion rarely increased productivity. Productive expansion, on the other hand, "was inherently more profitable than defensive expansion, and so set the direction in which the enterprise grew" (p. 489). As long as the expansion produces idle and/or transferable resources, in order words, as long as expansion produces slack, growth contains the seeds of further growth.

Penrose maintains that enterprise includes the willingness not only to take risks but also to search for ways of avoiding risk and still expand. In her view, enterprising management and ambition to make profits are necessary conditions for continued growth, and the management of growth requires two kinds of services: entrepreneurial services to take advantage of new possible avenues for profitable expansion, and managerial services to coordinate the use of resources profitably. Entrepreneurial services include entrepreneurial versatility (imagination and vision), fund-raising ingenuity, entrepreneurial judgment (in the absence of which the firm will tend to consistently make mistakes, over-estimate what it can do and guess wrongly the future course of events) and 
entrepreneurial ambition. Managerial services involve the development of interpersonal relations that take time to evolve in order for a newly hired employee to become fully productive. As a result, human resources cannot be purchased just-in-time like commodities, and management availability is, according to Penrose, the most constraining element to firm growth.

\section{Continued Existence}

In line with Penrose (1980), Chandler (1977) argues that the setting up and nurturing of a pool of managerial resources was essential for the successful growth of the modern firm because the managerial hierarchy provided the modern firm with the seeds of continued existence. It had a regenerating capability, which enabled the firm to outlive its members because "when a manager died, retired, was promoted or left an office, another was ready and trained to take his place" (Chandler, 1977, p. 8). Another seed of continued existence was the pursuit of a lifetime career by managers. As Chandler asserts, "for salaried managers the continuing existence of their enterprises was essential to their lifetime careers" (p. 10). Long-term commitment of managers combined with long-term investments were important requirements for the continued existence of the firm.

Sustaining a continued existence involves handling challenges that threaten the organization's survival. Organizational growth, for example, may bring about dysfunctional consequences, as large organizations are likely to become "too complex, too rigid, too impersonal, too inefficient and too inaccessible to outsiders" (Whetten, 1987, p. 341). In Barnard's view (1938), few organizations survive among innumerable failures because successful cooperation in organizations is the abnormal condition. The norm in human history, according to him, is faulty cooperation, disorganization, disintegration and the destruction of the organization. In line with Barnard (1938), Selznick (1957) asserts that organizational rivalry may be the most important, perennial problem in organizational life because it threatens the unity of the larger enterprise. Poor cooperation and ill-managed rivalry may cause the organization's dismantling and disappearance. In short, large, diversified firms require management to focus not only on developing the businesses' competitive advantage, but also to make the whole more valuable than the sum of its parts (Porter, 1987), and to prevent the firm from breaking apart. According to Selznick (1957), the self-preservation of an institution goes beyond survival, for it requires the preservation of organizational integrity.

\section{RESEARCH METHOD}

The longitudinal investigation on which this paper is based closely fits type 4 studies in Miller and Friesen's (1982) typology of longitudinal research. These authors define type 4 studies as those that describe scenarios of evolution of multiple organizations, use detailed information to justify conclusions, provide non-simplistic accounts, and are good for generating theories. The case histories of GE and WH are consonant with type 4 studies and with the investigation of why some positions of industrial dominance are persistently maintained and why early success stories so frequently turn into stories of decline and failure. These firms represent comparable extreme situations (Yin, 1989) and polar types (Eisenhardt, 1989) in which long-term success and failure is observable, being, therefore, representative of an emergent theory (Eisenhardt, 1989) on the long-term success and failure of organizations.

\section{Data Sources}

The study relied on various sources of historical information concerning the two firms and the constitution and development of certain industries they took part in, as well as more general environmental developments. Data sources included business bibliography books, historical studies published in books, academic journals, case studies and doctoral dissertations, Moody's Industrial 
Manual (1917-1995) reports, articles and advertisements (for GE and WH) in Fortune Magazine (1930-1999) and Business Week (1930-1947), Annual Reports of each company (1971-1999), and historical statistics. Detailed information on data sources has been reported elsewhere (Fleck, 2001).

\section{Data Preparation}

Accounting-based data. The accounting-based data of both companies over eight decades (19171997) called for the generation of longitudinally comparable quantitative indicators. I have conceived an indicator of the size of a firm in the American economy. It is defined as the firm's total annual sales as a percentage of the US GNP in a given year. This indicator provides a relative measure of size that suits highly diversified firms because it compares the firm to the economy as a whole. Plotting each firm's size indicator (1917 to 1997) produced a proxy for their growth trajectories in the economy.

Historical events data. I have used spreadsheets to organize historical evidence about the firms, the relevant environment, industry segments and individuals who played important roles in the history of the companies and the industry. I have made three types of lists: (i) a list with chronological entries of comparable organizational evidence, such as those regularly provided in Moody's Manuals; (ii) a list with chronological entries of idiosyncratic evidence about each company; (iii) a list of events about the industry, associating for each year two sorts of events: those taking place inside and those occurring around the American electrical manufacturing industry. This third type of list helped to characterize the environment, its pressures on industry firms and their corresponding responses.

\section{Data Analysis}

Stage 1. Visual inspection of GE's and WH's growth trajectory curves, corroborated by the calculation of correlation coefficients, identified that at first the patterns of growth and contraction of both companies greatly resembled one another and that this trend ceased to occur later on, signalling a change in pattern requiring explanation.

Stage 2. The scrutinizing of entries in the aforementioned events lists sought to find evidence of similarities and differences in behavior within each firm over time, and across the two companies at specific points in time. Within-case analysis (Eisenhardt, 1989) indicated the extent to which each firm's behavior was steady or variable over time, while cross-case analysis (Eisenhardt, 1989) showed the extent to which the companies' behavior consistently differed from or resembled each other over time.

Stage 3. Content analysis (Weber, 1990) of the firms' behaviors sought to group such behaviors into the smallest number of meaningful categories. An iterative process alternating theory and data sought to conciliate empirical patterns (Mintzberg \& Waters, 1982) and explanatory mechanisms (Bunge, 1996; Kiser \& Hechter, 1991). As the process converged, five categories of growth-related, managerial challenges could be distinguished. The different ways in which GE and WH responded to these challenges of growing and running ever larger organizations provided insight into two sets of behaviors that describe two ideal types (Doty \& Glick, 1994): the self-perpetuating and the selfdestructive. The proposed typology defines the set of ideal types, provides complete descriptions of each ideal type using the same set of dimensions and states the assumptions about the theoretical importance of each construct used to describe the ideal type, therefore meeting the requirements for proper development of typologies (Doty \& Glick, 1994, pp. 246-247). Organizational responses to the five challenges constitute descriptive dimensions of these ideal types, which are described in detail in the next section.

Stage 4. Mohr's notions of variance and process theory (Mohr, 1982) oriented the identification of relations among constructs. Variance theory "grows out of a foundation in the necessary and sufficient", while process theory "in the necessary alone" (Mohr, 1982, p. 36). Process theory elements include phases, cycles, states and the corresponding necessary conditions for the formation 
and change of phases, cycles and states. To identify necessary conditions, content analysis of the relevant literature sought to identify expressions like need(ed) to, require(d), necessary, necessitate, essential to, have(had) to and requisite, as well as the negative expression associated with a necessary condition: 'in the absence of $\mathrm{X}, \mathrm{Y}$ does not occur'. By associating constructs and relations, a process model was developed. This model describes a chain of requisites for the development of organizational self-perpetuation propensity. Model building sought conciseness in order to avoid a common pitfall encountered in process models: a myriad of boxes and arrows that is "in general merely a complicated description of many alternative ways in which a class of events might unfold, not a theoretical explanation of anything" (Mohr, 1982, p. 23).

\section{Post-study Analysis}

To check the external validity (Yin, 1989) of the theoretical ideas advanced in this paper, I performed exploratory work on Miller and Friesen's six successful and four unsuccessful archetypes $(1978,1984)$. Even though their studies in several respects differ from this one, enough commonalities existed for a comparison to be made. I made a content analysis of the authors' rich description of each archetype in order to comprehend how each one tended to respond to the five challenges that this paper suggests. For example, in their description of organizational structure, I searched for evidence of integrating and coordinating mechanisms or fragmentation, rather than for centralized/decentralized, functional/divisional features. The theory building section advances the proposed model as well as the results of the exploratory validity check.

\section{ANALYSIS RESULTS}

GE and WH pioneered in several technology-based businesses, and early on became the top two companies in the electrical industry. They electrified and illuminated cities, made thousands of consumer products and pioneered in electronics and telecommunications. Over time, they diversified both functionally and technologically. In addition to inventing and manufacturing, they branched out into marketing, distribution and finance. To develop increasingly complex products and systems, they extended their knowledge into the electrical, mechanical, chemical and nuclear fields. In doing so, both companies experienced continuous growth periods, reaching gigantic sizes. In fact, from the time the first Fortune 500 list was published until WH's disappearance, both companies were listed among the 30 largest US companies. Figure 1 portrays their growth trajectories over 8 decades. 
Figure 1: Growth Trajectories of General Electric and Westinghouse

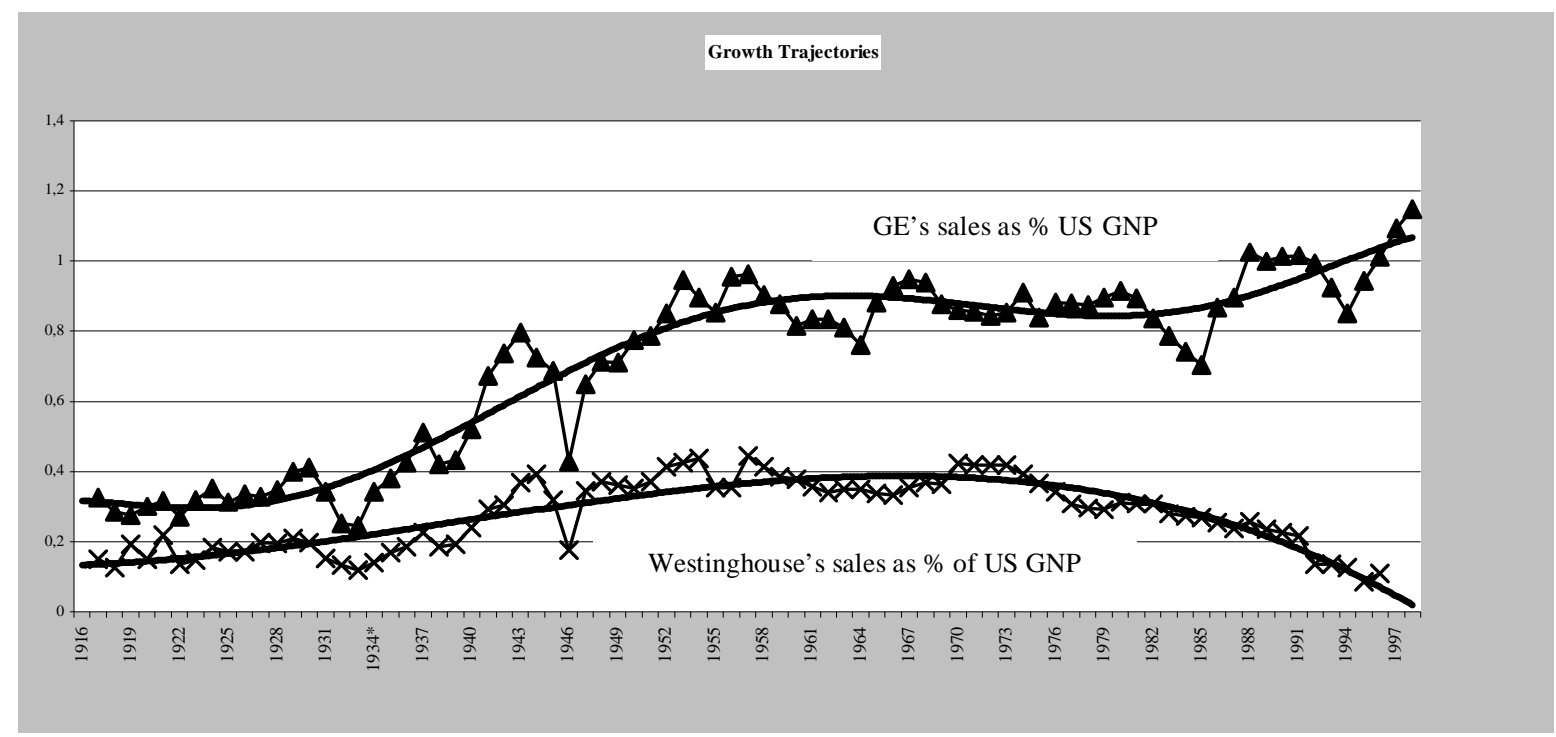

Source: elaborated by the author based on Moody's Industrial Manual (1917-1995) and Mitchell (1998).

GE's sales essentially increased over time, while WH's consistently decreased in the last decades of existence. Moreover, the two companies performed a quite synchronized growth path for many decades. Indeed, the correlation between GE's and WH's sales relative to the US GNP was 0.967 from 1917 to 1960 , and -0.405 from 1961 to 1996. Cross-case analysis revealed a large number of similarities between the two companies up to the 1960s and an increasing number of differences over the following two decades (see Table 1), while similarities vanished from the 1980s onward. Interestingly, within-case analysis suggests that each company behaved quite consistently throughout their existences, although each company would occasionally depart from its usual behavior. Superior technological innovation was a common trait in both companies. Nevertheless, they consistently differed in dealing with five other issues (see Table 2).

Table 1: GE \& WH: Similarities and Differences

\begin{tabular}{|c|c|c|}
\hline & Similarities & Differences \\
\hline $\begin{array}{l}\text { Up to the } \\
1960 \mathrm{~s}\end{array}$ & $\begin{array}{l}\text { Businesses, markets, products, } \\
\text { technological regimes, economic ups and } \\
\text { downs, legislation }\end{array}$ & $\begin{array}{l}\text { GE's industry coordination role through } \\
\text { patent licenses, suppliers agreements, partial } \\
\text { equity in national and international electrical } \\
\text { firms; GE's largest diversification during } \\
\text { WWII }\end{array}$ \\
\hline 1960-1980 & $\begin{array}{l}\text { Participation in the electrical conspiracy; } \\
\text { were caught short of capacity in lamps and } \\
\text { appliances in the absence of the patent } \\
\text { licenses; entered several minor unprofitable } \\
\text { ventures in high-tech and in non high-tech } \\
\text { businesses; faced a changing environment: } \\
\text { increasing foreign competition, labor } \\
\text { strikes, and high inflation; lost ground in } \\
\text { electronics; entered the nuclear field; } \\
\text { engaged in the defense business; R\&D labs } \\
\text { developed several innovations }\end{array}$ & $\begin{array}{l}\text { WH took a piecemeal expansion approach } \\
\text { both domestically and internationally, while } \\
\text { GE did not; WH took major non high-tech } \\
\text { initiatives: land development, car rental, home } \\
\text { building, mail order, while GE took minor non } \\
\text { high-tech initiatives; GE took major high-tech } \\
\text { initiatives in addition to the defense field: } \\
\text { computers, aircraft turbines, plastics, while } \\
\text { WH's high-tech initiatives were mainly in the } \\
\text { defense field; GE hedged against uranium } \\
\text { price hikes, while WH did not }\end{array}$ \\
\hline
\end{tabular}

Source: author's historical analysis 
Table 2: GE \& WH: Consistent Behavior throughout Their Existences

\begin{tabular}{|l|l|l|l|}
\hline & \multicolumn{1}{|c|}{ Issue } & \multicolumn{1}{c|}{ GE } & \multicolumn{1}{c|}{ WH } \\
\hline $\mathbf{1}$ & Technology & Superior innovation & Superior innovation \\
\hline $\mathbf{2}$ & Risk assessment of situations & Careful & Deficient/lacking \\
\hline $\mathbf{3}$ & $\begin{array}{l}\text { Handling inter organizational } \\
\text { relations }\end{array}$ & Pro-active/fashioning & Reactive/ accepting \\
\hline $\mathbf{4}$ & Organizing & Efforts to integrate the parts & $\begin{array}{l}\text { Propensity to foster } \\
\text { fragmentation }\end{array}$ \\
\hline $\mathbf{5}$ & $\begin{array}{l}\text { Source of top \& senior } \\
\text { management }\end{array}$ & Internal & External \\
\hline $\mathbf{6}$ & Solving administrative problems & Systematic & Ad hoc \\
\hline Source: author's historical analysis &
\end{tabular}

Cross-case and within-case analyses have suggested five types of growth-related challenges as well as the firms' polar responses to them (see Table 3). The issues presented in Table 2 inspired the challenges presented in Table 3 as follows: enterprising challenge (issues 1 and 2); navigating challenge (issue 3); diversity challenge (issue 4); managerial resources challenge (issue 5); and complexity challenge (issue 6).

Table 3: Five Organizational Challenges

\begin{tabular}{|c|c|c|}
\hline Challenge & Challenge & Polar Responses to Challenge \\
\hline Enterprising & $\begin{array}{l}\text { Promoting continued } \\
\text { entrepreneurship by } \\
\text { fostering the firm's } \\
\text { willingness to carry out } \\
\text { reinforcing, value-creating } \\
\text { expansion while also } \\
\text { preventing the } \\
\text { organization's overexposure } \\
\text { to risk }\end{array}$ & $\begin{array}{c}\text { High-reaching } \\
\text { (High level of ambition, } \\
\text { versatility, imagination, } \\
\text { vision, fund-raising } \\
\text { ingenuity, and judgment, } \\
\text { using productive- \& } \\
\text { hybrid-motivated moves) }\end{array}$ \\
\hline $\begin{array}{l}\text { Navigating into } \\
\text { the Dynamic } \\
\text { Environment }\end{array}$ & $\begin{array}{l}\text { Dealing with the } \\
\text { organization's multiple } \\
\text { stakeholders in order to } \\
\text { secure value capture and } \\
\text { organizational legitimacy }\end{array}$ & 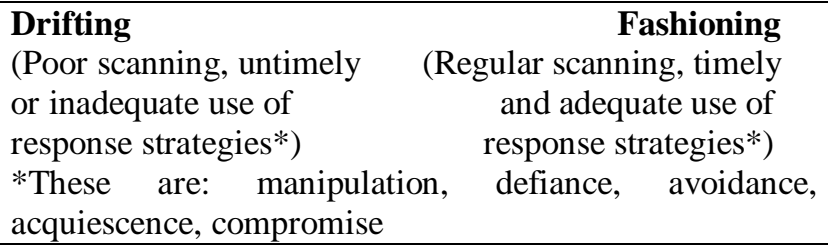 \\
\hline $\begin{array}{l}\text { Diversity } \\
\text { Management }\end{array}$ & $\begin{array}{l}\text { Sustaining the firm's } \\
\text { integrity in the face of } \\
\text { increasing organizational } \\
\text { conflicts and rivalry }\end{array}$ & $\begin{array}{c}\text { Integration } \\
\text { (Successful } \\
\text { development of } \\
\text { bonding relations and } \\
\text { coordinating capabilities) }\end{array}$ \\
\hline $\begin{array}{l}\text { Managerial } \\
\text { Resources } \\
\text { Provisioning }\end{array}$ & $\begin{array}{l}\text { Steadily equipping the firm } \\
\text { with necessary qualified } \\
\text { human resources }\end{array}$ & $\begin{array}{c}\text { Early } \\
\text { (Planned in advance } \\
\text { actions) }\end{array}$ \\
\hline $\begin{array}{l}\text { Complexity } \\
\text { Management }\end{array}$ & $\begin{array}{l}\text { Managing complex issues } \\
\text { and solving problems of } \\
\text { increasing complexity so as } \\
\text { to avoid risks to the } \\
\text { organization's existence }\end{array}$ & $\begin{array}{r}\text { Systematic } \\
\text { (Strong problem solving } \\
\text { capabilities promoting } \\
\text { comprehensive search for } \\
\text { solutions and } \\
\text { fostering learning) }\end{array}$ \\
\hline
\end{tabular}

Source: theoretical development by the author 


\section{Challenge \# 1: Enterprising}

The enterprising challenge consists of developing the a firm's willingness to expand on a continuing basis. It comprises the firm's willingness to take risks, to search for ways of avoiding risk and still expand (Penrose, 1980) and to achieve continuing growth instead of one-time growth. Fullfledged, high-reaching responses combine entrepreneurial services, i.e., ambition, versatility (imagination and vision), fund-raising and judgment (Penrose, 1980), and reinforcing expansion moves that put in motion a reinforcing process of generating new possibilities for expansion and value creation (Chandler, 1977; Penrose, 1980). In poor, satisficing responses, entrepreneurial services are but partially rendered, i.e., they lack one or more aspects (ambition, versatility, fund-raising, judgment), and/or expansion moves give rise to one-time growth, failing to promote reinforcing expansion mechanisms.

According to Chandler's account (1977), productive expansion, which gives rise to economies of scale, scope and/or speed, is more likely to produce continuing growth than defensive expansion, which seeks to reduce uncertainties and protect existing businesses. Typical defensive expansion includes vertical integration and horizontal acquisitions that seek to reduce the strength of competitive forces in the industry (Porter, 1980). My analysis has suggested the possibility of two other types of motives: hybrid, i.e., both productive and defensive, and nil, i.e., neither productive nor defensive. Hybrid motives allow a firm to improve its efficiency and protect existing businesses, while nil motives typically refer to empire-building expansion (Penrose, 1980). The firm that undertakes only defensive and nil motivated growth is highly likely to foment one-time growth, experience increasing difficulties to expand on a continuing basis and face renewal problems in the long run.

\section{Challenge \#2: Navigating into the Dynamic Environment}

The navigating challenge is about successfully dealing with the organization's multiple stakeholders in a changing environment so as to secure value capture and organizational legitimacy. While the enterprising challenge concerns mostly value creation, the navigating challenge emphasizes value capture (Bowman \& Ambrosini, 2000; Lepak, Smith, \& Taylor, 2007). Full-fledged, fashioning responses to the navigating challenge comprise the regular scanning of environmental pressures, and the timely and adequate use of the full range of strategies (Oliver, 1991) to shape the environment (manipulation and defiance strategies), to neutralize pressures (avoidance strategies), and to adjust to situations that lie outside the firm's reach (compromise and acquiescence strategies). Drifting responses perform poor scanning and/or untimely and/or inadequate use of response strategies. This causes the organization to drift and puts the firm's survival at risk for several reasons: important opportunities for value capture may be lost, the firm's readiness to promote and react to change may weaken, and threats to organizational legitimacy may be left unattended.

\section{Challenge \#3: Managing Diversity}

The diversity management challenge has to do with sustaining the firm's integrity as the firm experiences increasing diversity. In fact, the growing firm faces the problems and opportunities of workforce diversity (Page, 2007) as well as structural and business diversity, i.e., differing markets, products, technologies and human resources proliferate. Heterogeneity among the constituent parts of the organization gives rise to conflicts and rivalry, thereby threatening organizational unity. Successful management of organizational diversity distinguishes heterogeneous from homogeneous organizational elements and foments suitable bonding relations (Stickland, 1998). It promotes resource sharing for homogeneous aspects and resource exchanging and/or combining otherwise.

Bonding through sharing comprises not only common goods, facilities, personnel and services but also less tangible items such as organizational reputation, organizational myths (Selznick, 1957) and shared perceptions of sustained threats to organizational existence. By making use of standardization processes, this type of bonding is likely to promote economies of scale, scope and speed (Chandler, 
1977, 1990). To the extent that shared resources are valuable and rare due to unique historical conditions, this bonding is likely to confer upon the organization resources that are hard and costly to imitate (Barney, 1997).

Bonding through exchanging and combining includes both the physical exchange and combination of goods, facilities, personnel and services, and organizational processes involving complex interactions and strong relationships between organizational elements. This bonding is likely to provide the organization with processes that are hard and costly to imitate due to their embedded social complexity (Barney, 1997).

In both cases, the building of bonding relations calls for coordination capabilities. These capabilities include the proper implementation of coordinating mechanisms such as liaison positions, task forces, standing committees, integrating managers and integrating departments (Galbraith, 1973; Lawrence \& Lorsch, 1967; Mintzberg, 1979). Successful implementation of coordination mechanisms does not extinguish heterogeneity. Rather, it makes constructive use of heterogeneous elements, stimulating organizational integration. Poor coordination capabilities, on the other hand, predispose organizational members to refrain from cooperating. As a result, members will likely seek increasing autonomy, which ends up producing organizational fragmentation. In short, full-fledged, integration-oriented responses to the diversity challenge promote the sustainability of organizational integrity, while poor, fragmentation-oriented responses weaken organizational integrity.

\section{Challenge \#4: Provisioning Managerial Resources}

The provisioning challenge deals with steadily equipping the firm with needed qualified human resources, i.e., anticipating needs, forming, retaining, developing and renewing these resources. Human resources formation, retention, development and renewal are vital for the continuing growth (Penrose, 1980) and continued existence (Chandler, 1977) of the firm. Failure to provide the necessary managerial talent at the right time may not only preclude expansion but also weaken the organization's integrity, such as in the case of massive recruitment of management. Early responding to the challenge through actions that are planned in advance allows for equipping the firm with the necessary resources, while late responding through after the fact actions weakens the organization's integrity.

\section{Challenge \#5: Managing Complexity}

The complexity challenge has to do with managing complex issues and solving problems that involve a large number of interdependent variables in order to avoid putting the organization's existence at risk as a result of faulty assessments of the situation. Complex problem solving requires systematic procedures of data gathering, analysis, decision-making and implementation. The complexity challenge, therefore, affects the quality of the responses to all other challenges. Systematic problem solving promotes comprehensive searches for solutions and fosters learning, contributing highly needed capabilities to successfully face the enterprising, the navigating, the diversity and the managerial provisioning challenges. Ad hoc problem solving, on the other hand, favors the quick search for solutions and precludes learning, contributing substantial organizational liabilities to the organization.

The larger the organization, the more complex it is likely to be. The more complex, the more vital systematic problem solving will be to prevent the organization from committing the whole company on the basis of partial assessment of the situation, and thereby threatening organizational integrity (Selznick, 1957). On the other hand, the firm that institutionalizes the firefighting mode (Winter, 2003) to solve problems puts the continuity of its existence in danger. 


\section{Success and Failure throughout the Existences of GE and WH}

Historical evidence suggests that since GE's first years its responses to the five challenges to a large extent matched the right pole set of responses (Table 3). GE occasionally departed from the right pole when dealing with some challenge or other, but managed to reorient itself, and thanks to its highly developed systematic problem solving capabilities, it avoided overexposure to risk. On the other hand, more often than not, WH responded poorly to the growth-related challenges (left pole responses in Table 3). Moreover, historical analysis suggests that GE has managed to learn from critical situations, while WH did not. For example, shortly after its foundation, GE almost went bankrupt as a result of the abrupt Financial Panic of 1893. GE's painful restructuring and shrinkage inspired the institutionalization of several risk-awareness organizational policies, and turned GE's risk-taking President into a conservative investor and a leader that fomented organizational integration. Although the 1893 Panic did not affect WH, its financial well-being was severely affected by the 1907-8 depression in the American economy. Unlike GE, WH's President was ousted on account of the financial crisis, giving rise to a major organizational fragmentation that persisted throughout WH's existence. On top of that, WH never changed into a risk-aware company.

Superior innovation was common to both companies. By combining innovation with a concern for organizational integration, careful risk-assessment and systematic problem solving, GE has developed tight-loose characteristics that typify ambidextrous organizations (Tushman \& O'Reilly, 1996). WH's superior innovation was, however, combined with organizational fragmentation, deficient riskassessment and ad hoc problem solving. This gave rise to a very loosely-coupled organization (Orton \& Weick, 1990) that lacked all three compensations for loose coupling: strong leadership, focused attention and shared values. Historical analysis suggests that WH's declining process was more a suicidal trajectory (Whetten, 1980) than a triumph of GE over its rival. But why did WH last for so many decades? The fact is that up to WWII GE steadily helped to build a protective industry structure that enabled most industry players to be quite profitable. Such benign conditions helped WH to institutionalize a set of behaviors that were conducive to organizational self-destruction. In sum, no hostile, homicidal environment forced WH's dissolution. Rather, WH's technological values were not strong enough to neutralize the disintegration initiative that its largest shareholder championed in the 1990s. Throughout its existence, weak organizational pillars supported WH's technological capabilities. This suggests that WH followed a self-destructive path in the course of which it developed a set of liabilities that undermined continuing growth efforts and gave rise to a fragmented organization that did not manage to navigate successfully on its own after the dismantling of the protective industry structure. GE, on the other hand, has consistently made use of right pole responses (Table 3) and, above all, it has consistently been developing the ability to handle conflicting pressures in a way that preserves organizational integrity and promotes renewal through continuing growth.

\section{THEORIZING ON THE LONG-TERM SUCCESS AND FAILURE OF ORGANIZATIONS}

In this section, analytic generalization (Yin, 1989) from the comparative study addresses the question of why some positions of industrial dominance are persistently maintained, and why early success stories so frequently turn into stories of decline and failure.

Organizational success (failure) has to do with the organizational ability (inability) to manage growth-related challenges. The right pole responses (Table 3) describe a set of capabilities required for organizational long-term success, while the left pole characterizes a set of liabilities conducive to organizational failure. The sets of capabilities and liabilities constitute organizational archetypes of success and failure respectively. I have coined two terms to designate these archetypes: those firms that behave according to the set of capabilities (right pole responses) are called self-perpetuating organizations, whereas those whose behavior fits the set of liabilities (left pole) are named selfdestructive organizations. 
Self-perpetuating and self-destructive organizations are organizational ideal types (Doty \& Glick, 1994) and constitute the extreme poles of a continuum of possible organizational states. On acount of local rationality (Cyert \& March, 1963), different responses to a given challenge may coexist in the same corporation. As a result, no organization behaves entirely in accordance with either ideal type. Rather, real organizations operate in intermediary states between the two polar states. The more capabilities an organization develops and makes use of, the more it approaches the self-perpetuation pole, and the more liabilities it develops and relies on, the nearer it is to the self-destruction pole. Finally, the greater the organizational propensity to nurture self-perpetuating capabilities, the higher the chances the organization will experience success; and the greater the organizational propensity to develop self-destructive capabilities, the higher the chances it will experience decline and face the threat of extinction.

From this perspective of organizational success and failure, an organization is likely to persistently maintain positions of industrial dominance to the extent that it nurtures a propensity to self-perpetuate. On the other hand, as a successful organization fails to nurture a propensity to self-perpetuate it will eventually turn into a self-destructive organization and will face decline and failure. The empirical study has identified organizational behaviors conducive to organizational long-term success and failure, having, therefore, contributed answers to the questions of continued dominance, and of early success turning into decline and failure. From a theoretical viewpoint, however, a deeper understanding of why such behaviors are likely to produce organizational success and failure is needed. A process model (Mohr, 1982) conducive to organizational self-perpetuation is proposed (see Figure 2) and its rationale is presented below. To facilitate understanding, I have numerically labeled the relations among constructs in the model (1 to 8) and will discuss them in sequence. 
Figure 2: Model of Requisites for the Development of Organizational Self-perpetuation Propensity

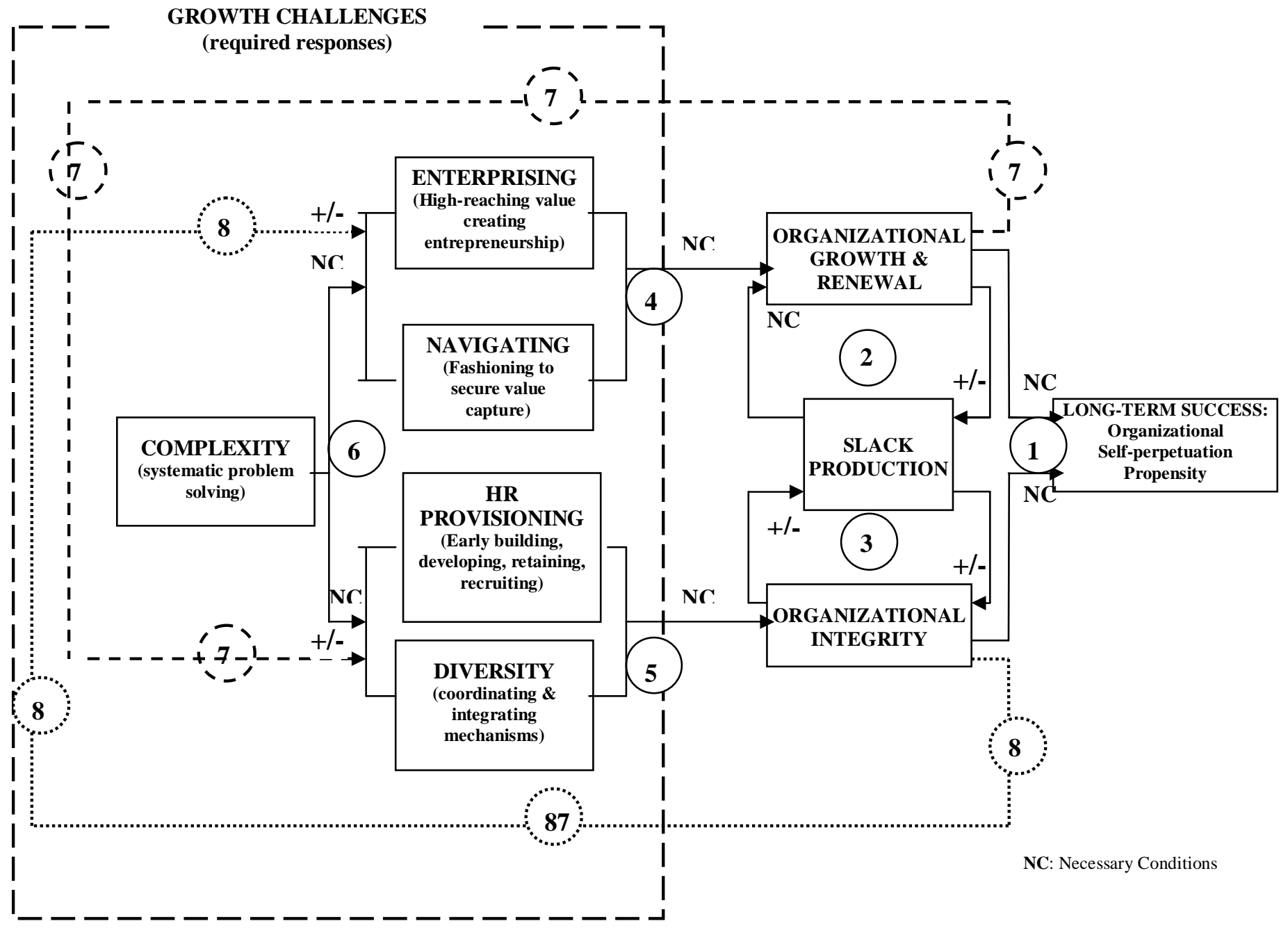

Source: theoretical development by the author 


\section{Relations Associated with Label 1}

There are two necessary conditions for organizational long-term success, i.e., for the development of a self-perpetuating propensity: continued renewal through organizational growth and organizational integrity preservation.

Renewal through growth. Both Penrose (1980) and Chandler (1977) have mentioned the possibility of a firm developing a self-renewing capability. More recently, renewal has been emphasized in the dynamic capabilities perspective (Eisenhardt \& Martin, 2000; Helfat at al., 2007; Teece, Pisano, \& Shuen, 1997; Winter, 2003). The self-renewing capability comes from slack resources, i.e., under-utilized, transferable skills and resources produced in the course of an expansion. Because of the indivisibility property of newly acquired resources (Penrose, 1980), the firm inevitably ends up with excess resources that can be applied to other activities. This gives rise to related expansion moves made to increase operational efficiency. By doing so, new types of slack are produced, and new expansion can be pursued. Chandler calls this process continuing growth. The continuing growth process provides highly appreciated renewal seeds for coping with the changing condition of the environment. While GE consistently engaged in continuing growth processes, from the late 1960s on, WH replaced continuing growth processes with unrelated acquisitions, considerably reducing its renewal seeds. Since from a long-term perspective no environment is stable, setting in motion continuing growth processes becomes an organizational requirement for long-term success.

Organizational integrity. Growth, however, contains potential threats to healthy organizational longevity. As Chandler (1977) mentioned, cash flow pressures exerted by high fixed costs may lead to expansion that produces a higher but less profitable use of resources. In addition, as the growth process develops, multiple pressures may threaten organizational integrity: ill-managed rivalry (Selznick, 1957), poor cooperation (Barnard, 1938), weak coordination skills (Lawrence \& Lorsch, 1967), strategy formulation and implementation supported by incomplete assessments of the situation (Selznick, 1957), and poor recruiting (Selznick, 1957). Conflicts of interest underlined in other theoretical perspectives, such as the agency theory (Jensen \& Meckling, 1976), corporate governance (Daily, Dalton, \& Cannella, 2003), stakeholder theory (Gomes \& Gomes, 2007), corporate ethics (Almeida, 2007) and corporate social responsibility (Matten \& Moon, 2008) also contribute insights into individual, organizational and institutional pressures that threaten organizational integrity. Left unattended, these pressures may threaten the firm's integrity and lead to its break up and selfdestruction. Historical evidence suggests that both GE and WH faced continued integrity threats, and that GE was not only aware, but consistently engaged in fomenting the integration of its parts. WH's inability to handle conflicts productively, on the other hand, continuously fostered organizational fragmentation. Therefore, preserving organizational integrity is another requirement for long-term success.

In short, to persist and perform well, organizations must renew through profitable growth, and preserve their integrity, therefore having to overcome the challenges of renewal and integrity preservation. Thus, it can be said that long-term success requires the development of two abilities: organizational renewal through continuing growth processes and organizational integrity preservation to enable the firm to continue existing.

\section{Relations Associated with Labels 2 and 3}

Slack is made up of all sorts of resources that exceed what is needed for the organization to operate at a given desired performance level. These resources include both hard and soft categories, such as people, equipment, capital/profits, brands, reputation, etc. The functions of slack in organizations include: maintaining the coalition, easing conflicts, buffering against uncertainty, enabling innovation, allowing satisficing decision-making, and fueling organizational political fights (Bourgeois, 1981; 
Bowen, 2002). Slack production plays a distinguishing role in the development of self-perpetuation propensity, in that it affects both organizational renewal and integrity preservation.

Slack fuels continuing growth and vice-versa (label 2). Since slack enables innovation and exploration (Cheng \& Kesner, 1997; Sidhu, Volberda, \& Commandeur, 2004), slack fuels continuing growth. Moreover, slack is a necessary condition for organizational renewal. As Penrose (1980) has stated, some resource categories, such as management, are required to be available before expansion takes place; otherwise, the quality/effectiveness and speed of the expansion move will be compromised. On the other hand, overuse of slack's buffering function may foster a defensive attitude that precludes innovation initiatives. Growth fuels slack because, as both Penrose (1980) and Chandler (1977) have remarked, the growth process produces underutilized resources that join the pool of resources available for further expansion. But, since growth may also make use of existing slack resources, once undertaken, expansion moves may increase and/or decrease organizational slack both qualitatively and quantitatively. As a matter of fact, WH's string of unrelated diversification moves from the late 1960s to the 1990s consumed rather than produced further slack.

Slack also interacts with the fostering of organizational integrity (label 3). Slack may positively influence organizational integrity when applied, for example, to develop and implement integrating and coordinating mechanisms. Throughout its existence, GE has consistently made use of training as an integrating tool of its large and diverse workforce. Slack may, however, negatively affect organizational integrity. For one slack may fuel political battles for resources. In addition, slack is likely to erode the organization's values and character and promote organizational disintegration if it is heavily used to maintain the organizational coalition, and/or to compensate for inefficiency, such as faulty operating procedures, deficient communication and poor handling of organizational conflicts. Throughout the process, wherein slack fosters integrity or fails to do so, slack consumption may generate or release slack, increasing or decreasing the pool of available slack. Both GE and WH consumed slack in political fights and other dysfunctions. What differed was the relative proportion of productive use of slack: high at GE, and medium (during early times) to low (throughout the final decades) at WH.

It is worth mentioning that sustained high economic performance provides the firm with an essential slack for organizational integrity preservation. For one, it undoubtedly helps to nurture the organization's propensity to continue to exist because, in principle, each stakeholder's aspiration can conceivably be fulfilled. In addition, sustained high performance can eliminate or postpone plans for discarding the organization or some part of it. On several occasions, GE's outstanding performance has neutralized the financial market pressure on it to dismember its businesses, whereas WH's poor performance throughout the 1990s prompted its main shareholder to trigger the firm's disintegration.

\section{Relations Associated with Label 4}

Organizational renewal through continuing growth is fostered (or precluded) through the development of capabilities (liabilities) to respond to two challenges: enterprising and navigating into the dynamic environment. Organizational responses in the vicinity of the right pole (See Table 3) constitute necessary conditions for the promotion of organizational renewal through growth. Let us see why. When it comes to the enterprising challenge, as Penrose (1980) has stated, in the absence of high-reaching entrepreneurial services (ambition, versatility, fund-raising and judgment) that set in motion non-threatening reinforcing expansion (Chandler, 1977) the firm will fail to grow, renew and ultimately create value on a continued basis. As for the navigating challenge, if the firm consistently fails to regularly perform environmental scanning, to shape the environment whenever possible and to neutralize pressures and adjust to situations whenever needed, it will not succeed in capturing value from its enterprising initiatives. As a result, the firm will fail to feed the slack pool with financial slack. In short, right-pole-responses to those two challenges constitute necessary conditions for promoting renewal through growth on a continued basis. Up to the1960s, a period of synchronized growth for $\mathrm{GE}$ and $\mathrm{WH}$, both companies proactively responded to the enterprising and navigating challenges, although GE responded more intensively than WH. From the 1960s onward, however, 
WH's responses would progressively fail to create and capture value and, what is worse, they would cause WH's overexposure to risk. As a result, WH underwent size reduction, while GE managed to find its way to further growth (see Figure 1).

\section{Relations Associated with Label 5}

Organizational integrity is fostered (or precluded) through the development of capabilities (liabilities) to respond to two other challenges: managing diversity and provisioning qualified human resources. Organizational responses in the vicinity of Table 3's right pole constitute necessary conditions for the preservation of organizational integrity (Selznick, 1957). A number of factors that are typical of social systems foment organizational fragmentation: rivalry (Selznick, 1957), the coexistence of numerous sub-coalitions (Cyert \& March, 1963) and failure of cooperation (Barnard, 1938). When it comes to the diversity challenge, in the absence of strong capabilities for establishing bonding relations and coordination capabilities, organizational integrity is precluded because the disaggregating effects brought about in the course of expansion moves will not be neutralized but rather will produce organizational fragmentation. Another typical feature of social systems is that relations take time to develop (Penrose, 1980). For example, in the case of external recruitment, if newly hired people are immediately required to fight in the competitive landscape for a company they barely know, they are likely to rely on hiring people they are used to working with. This may give rise to the formation of new sub-coalitions that do not have the time to merge into the existing social system and consequently provoke a disaggregating effect that threatens organizational integrity. As a result, the organization will fail to preserve organizational integrity in the absence of previously planned recruitment and of actions regarding the development and retention of qualified human resources. In other words, the right-pole-responses to the diversity and provisioning challenges constitute necessary conditions for preserving organizational integrity. Throughout its whole existence, GE has not only struggled to fight the fragmentation threat that growth processes bring about, but has also meticulously taken care of the increasing need for qualified human resources. As a result, GE has made deliberate effort to foster the unity of such a diverse organization. WH, on the other hand, barely ever fought fragmentation and it failed to systematically develop managerial resources. In short, throughout its existence, WH exhibited a low level of organizational integrity, which partly explains why it was dismantled so quickly.

\section{Relations Associated with Label 6}

As mentioned above, the complexity challenge affects the quality of responses to all other challenges. Creating value on a continued basis, ensuring value capture, steadily equipping the firm with qualified resources and sustaining organizational integrity are problems that require systematic treatment. In the absence of systematic problem solving, sooner or later the firm will face overexposure to business risk, leave unattended organizational legitimacy threats, fail to provision qualified human resources and fail to neutralize the pressures towards fragmentation. Moreover, in the absence of a systematic problem solving attitude, today's wisdom and mistakes will not become part of the organization's knowledge base, supposing that such a data base exists, which is hardly likely in the case of ad hoc problem solving. Ultimately, the firm will fail to develop the capability to learn. Therefore, unless the firm engages in systematic problem solving, its solutions will fail to consider the consequences for both the whole and its parts (Selznick, 1957). This opens the way for fire-fighting behavior (Winter, 2003), fuels organizational conflict and over an extended period of time threatens organizational existence (Barnard, 1938). At WH, George Westinghouse inaugurated a systematic approach to innovation that continued to be used by WH's engineers until the 1990s. This, however, was not consistently applied to management. In contrast to GE, understanding reality was not systematically pursued at WH. As a result, in general, WH's responses to the four other challenges were less effective than GE's. 


\section{Relations Associated with Labels 7 and 8}

Regarding label 7, organizational renewal through continuing growth places added pressure on the diversity and human resources provisioning challenges, as expansion may require new management and new or improved coordinating and integrating mechanisms. This is in line with Chandler's assertion (1962) that the growth of companies requires adjustments in their organizing. As for label 8, preserving organizational integrity also puts additional pressure on the enterprising and navigating challenges. The preservation of the organizational integrity of an increasingly more diversified firm calls for additional slack generation to fulfill an increasing quantity and variety of stakeholders as well as for creating career opportunities in order to retain valuable human resources. As both demands are conceivably attainable through growth, the preservation of organizational integrity puts extra pressure on value creation (enterprising challenge) and value capture (navigating challenge). The other way around, in the event of organizational contraction or stagnation, the diversity and provisioning challenges may be reduced. Subsequently, such a change may reduce the pressures for value creation (enterprising challenge) and value capture (navigating challenge).

\section{Checking External Validity}

Being ideal types, the self-perpetuating and self-destructive archetypes constitute extreme states of organizational existence. Real organizations lie in between the poles. Historical analysis suggests that GE's position along the organizational states continuum seems to have fluctuated in the vicinity of the self-perpetuating pole. $\mathrm{WH}$, on the other hand, never came as close to the self-perpetuation pole as $\mathrm{GE}$, and from a certain point on, WH moved towards the self-destruction pole. An exploratory examination of Miller and Friesen's (1978, 1984) successful (six) and unsuccessful (four) archetypes has also indicated that the companies those authors analyzed did lie somewhere in between the two poles. Interestingly, all unsuccessful archetypes responded poorly to the enterprising, navigating, diversity and complexity challenges. Three out of four unsuccessful archetypes also responded poorly to the human resources provisioning challenge, while the fourth one could not be assessed due to insufficient information on this issue. Table 4 summarizes the exploratory analysis for unsuccessful types. 
Table 4: Miller and Friesen's Archetypes (1984) vis-à-vis the Growth-related Challenges

\begin{tabular}{|c|c|c|c|c|c|}
\hline $\begin{array}{l}\text { CHALLENGES } \\
\text { ARCH. }\end{array}$ & ENTERPRISING & $\begin{array}{c}\text { NAVIGATING INTO } \\
\text { THE ENV }\end{array}$ & $\begin{array}{c}\text { DIVERSITY } \\
\text { MANAGEMENT } \\
\end{array}$ & $\begin{array}{c}\text { HR } \\
\text { PROVISIONING }\end{array}$ & $\begin{array}{c}\text { COMPLEXITY } \\
\text { MANAGEMENT }\end{array}$ \\
\hline F1: Impulsive & $\begin{array}{l}\text { Firms badly } \\
\text { overextend } \\
\text { themselves (p. 92) }\end{array}$ & $\begin{array}{l}\text { Wrong variety of } \\
\text { environmental scanning } \\
\text { (p. 93) }\end{array}$ & $\begin{array}{l}\text { Vertical fragmentation: top } \\
\text { mngt isolated } \\
\text { Departments and divisions often } \\
\text { work at cross-purposes (p. 92) } \\
\text { Efforts are non integrated (p. } \\
\text { 92) } \\
\text { Poor internal communication } \\
\text { systems (p. 93) }\end{array}$ & $\begin{array}{l}\text { There is not enough } \\
\text { managerial talent to } \\
\text { administer the } \\
\text { expanded enterprise } \\
\text { (p. 92) }\end{array}$ & $\begin{array}{l}\text { Over time, new acquisition } \\
\text { targets are not examined } \\
\text { closely. Weak companies are } \\
\text { purchased. } \\
\text { Lack of effective controls. } \\
\text { Resources are seriously } \\
\text { depleted by divisional } \\
\text { operating problems (p. 92) }\end{array}$ \\
\hline $\begin{array}{l}\text { F2: Stagnant } \\
\text { Bureaucracy }\end{array}$ & $\begin{array}{l}\text { Satisficing, though } \\
\text { not risky }\end{array}$ & $\begin{array}{l}\text { Avoidance strategy: } \\
\text { any changes managers } \\
\text { become aware of are } \\
\text { written off as fads or } \\
\text { anomalies that will pass } \\
\text { (p. 94) } \\
\text { New ideas are } \\
\text { discarded. }\end{array}$ & $\begin{array}{l}\text { Very high level of conflict } \\
\text { between upper-level (older) and } \\
\text { lower-level (younger) managers } \\
\text { (p. 95) } \\
\text { Poorest internal } \\
\text { communications (p. 94) }\end{array}$ & $\begin{array}{l}\text { Failure in } \\
\text { acknowledging and } \\
\text { retaining talent: The } \\
\text { firm loses promising } \\
\text { middle managers to } \\
\text { more progressive } \\
\text { competitors (p. } 95 \text { ) }\end{array}$ & $\begin{array}{l}\text { Data fail to point to the } \\
\text { real problem of rethinking } \\
\text { the product mix (p. 94) }\end{array}$ \\
\hline F3: Headless Giant & $\begin{array}{l}\text { Aimless } \\
\text { organization (p. } \\
98) .\end{array}$ & $\begin{array}{l}\text { Unable to adapt to a } \\
\text { more dynamic, } \\
\text { competitive, } \\
\text { heterogeneous } \\
\text { environment (p. 97) }\end{array}$ & $\begin{array}{l}\text { Loosely coupled, diversified } \\
\text { fiefdoms of highly independent } \\
\text { departments and divisions (p. } \\
\text { 96) } \\
\text { Sub-units work at cross- } \\
\text { purposes (p. 97) } \\
\text { Reluctance to share information } \\
\text { (p. 97) }\end{array}$ & $\begin{array}{l}\text { NO INFORMATION } \\
\text { AVAILABLE }\end{array}$ & $\begin{array}{l}\text { Fragmented departments try } \\
\text { to deal with problems as } \\
\text { they arise (p. } 97 \text { ) }\end{array}$ \\
\hline F4: Aftermath & $\begin{array}{l}\text { Too many risks } \\
\text { are taken (p. 100) }\end{array}$ & $\begin{array}{l}\text { Scanning of markets is } \\
\text { minimal (p. 101) }\end{array}$ & $\begin{array}{l}\text { No integration of the old and } \\
\text { the new (p. 100) } \\
\text { Sharp division between new } \\
\text { managers and veterans (p. 100) } \\
\text { Lack of effective coordination } \\
\text { and integrative devices (p. 100) }\end{array}$ & $\begin{array}{l}\text { The firm has } \\
\text { occasionally been } \\
\text { faced with the } \\
\text { departure of } \\
\text { managerial talent (p. } \\
\text { 99) } \\
\text { A new team of } \\
\text { executives takes } \\
\text { control and tries a } \\
\text { turnaround (p. 99) }\end{array}$ & $\begin{array}{l}\text { Piecemeal, inexpensive } \\
\text { changes to solve problems } \\
\text { (p. 99) } \\
\text { New managers jump at } \\
\text { making immediate changes } \\
\text { without first trying to } \\
\text { uncover the roots of their } \\
\text { problems or to predict the } \\
\text { consequences of their actions } \\
\text { (p. 100) }\end{array}$ \\
\hline
\end{tabular}


Miller and Friesen's successful archetypes, on the other hand, tended to respond in a better way to the diversity and complexity challenges: their coordination mechanisms and information systems were more developed, although they varied among themselves, depending on the size of the firm. Interestingly, most successful archetypes (five out of six) handled at least one other challenge poorly, failing therefore to fulfill the set of necessary conditions for nurturing a self-perpetuation propensity. The successful archetype that apparently approached the most the self-perpetuating pole was the 'Adaptive in a Very Challenging Environment $\left(\mathrm{S}_{1 \mathrm{~B}}\right)$ ', which included Intel (in 1973) and DuPont (in 1950). Miller and Friesen's work (1978) classified DuPont in 1967 as a 'Giant Under Fire $\left(S_{3}\right)$ ', an archetype of large, formerly successful companies facing renewal difficulties. In other words, over this time period, DuPont would have reduced its degree of propensity to self-perpetuate.

This is entirely consistent with the proposed model (Figure 2). In fact, feedback relations associated with labels 7 and 8 indicate that over time the challenges faced by the organization may increase (in the course of a growth path, for instance) or decrease (in the course of a stagnation or shrinking path, for example). Consequently, the firm's propensity to self-perpetuate (or self-destruct) may also change over time.

\section{CONCLUSION}

Comparative analysis of twelve decades in the histories of General Electric and Westinghouse revealed that despite their comparable capabilities in the development of high technology, the companies differed in several respects. In fact, they tended to respond to growth-related, managerial challenges in quite opposite ways. As a result, while GE has pursued a quite consistent growth trajectory, WH disintegrated after 110 years of existence. Inductive theoretical work on historical data has advanced some building blocks for a theory of the long-term success and failure of organizations. Two organizational archetypes, representing extreme states of organizational existence, were described: the self-perpetuating and the self-destructive organization.

Most of the general management literature addressing organizational growth, corporate excellence and managerial success has been dealt with in practitioner-oriented books. This includes best-sellers such as 'In Search of Excellence' (Peters \& Waterman, 1982), 'Built to Last' (Collins \& Porras, 1994), and 'Good to Great' (Collins, 2001), to name a few. The integrated perspective advanced here differs from the existing literature on three major dimensions. First, these books focus one-sidedly on the paths to success, while the theory developed here also includes paths to failure. Second, these books put forward holistic frameworks, such as the $7 \mathrm{~S}$, or general, ill-connected lessons and guidelines for achieving corporate excellence, while the theory proposed here puts forward an integrated requisite model and offers explanatory mechanisms that can help management foster corporate health and preclude organizational self-destruction. Finally, the theory developed here explicitly includes a temporal perspective of success, which is somewhat absent in such books.

Reflecting on the accomplishments and shortcomings of conceptually derived typologies and empirically based taxonomies, Miller $(1999$, p. 29) has suggested a third approach on configurations, namely "studying configuration as a variable or quality within each organization that can create or destroy competitive advantage". In a sense, this study can be said to belong to this third approach because the self-perpetuating and the self-destructive archetypes in fact describe organizational capabilities and liabilities that help to create or destroy competitive advantage.

The self-perpetuating and self-destructive archetypes differ from most taxonomies, which "have justly been criticized for their lack of theoretical significance" (Miller, 1999, p. 30). As a matter of fact, the proposed archetypes constitute building blocks of an emergent theory of long-term success and failure of organizations. The theoretical contribution is twofold. The first one, of a descriptive nature, puts forward two organizational archetypes, the self-perpetuating and the self-destructive, 
which represent extreme states of organizational existence. The second contributes explanation, as it advances a model of requisites for the development of the organizational propensity to self-perpetuate. The model's chains of necessary conditions intertwined with variance relations and feedback mechanisms help us to understand why and how a self-perpetuating propensity may form or fail. Additionally, the model also has some predictive power, as it predicts that an organization will fail to develop a self-perpetuating propensity (and enjoy long-term success) if its responses to the set of growth challenges repeatedly fail to approach the right pole (Table 3).

According to Miller (1999), the quality of configuration can have important normative implications, as is the case of the proposed archetypes. For one, Table 3 provides guiding lights for managing for long-term organizational success, distinguishing appropriate from poor responses to five organizational challenges. In addition, the theoretical model (Figure 2) helps managers to assess the impact of critical decisions on the long-term well-being of the firm.

From a dynamic viewpoint, the model suggests that the organizational success state should be seen as a moving target. Although the nature of the requirements (the set of necessary conditions) for approaching the self-perpetuating pole remains constant, the levels at which responses should be given necessarily change over time. For example, what the enterprising challenge encompasses is definitely a function of the firm's size.

This has implications for the investigation of organizational change within a long-term perspective. From this perspective, organizational change can be seen as state change in a bi-dimensional state space. The first dimension represents states of organizational existence, whose polar values are the self-perpetuating and the self-destructive states. The other dimension concerns the state of the environment, which could be defined in terms of how easy (or difficult) it is for firms to create and capture value. While a 'forgiving' environment would easily enable value creation and value capture, an 'inhospitable' one would preclude value creation and/or value capture, and a 'challenging' environment would neither preclude nor easily enable value creation and value capture.

All those insights indicate some challenging avenues of research. Operationalizing the model's constructs would enable longitudinal studies to perform theory testing. Data-rich longitudinal studies could develop further theory by identifying representative intermediary states of organizational existence. Furthermore, in-depth studies on environmental conditions could suggest environmental states in function of value creation and value capture characteristics. Research efforts such as these would pave the way for the study of the dynamics of organizational success and failure comprising investigations of persistent success (Chandler, 1977), persistent failure (Meyer \& Zucker, 1989), and state change, i.e. from self-perpetuating to self-destructive and vice-versa. This might enable the investigation of a matter that is critical for researchers and practitioners: as a firm moves towards the self-destruction pole, would there be a point of no return?

\section{ACKNOWLEDGEMENTS}

The research reported in this paper has been partially financed by CNPq and FAPERJ. The author wishes to thank the anonymous reviewers for their comments.

\section{REFERENCES}

Almeida, F. (2007). Ética e desempenho social das organizações: um modelo teórico de análise dos fatortes culturais e contextuais. Revista de Administração Contemporânea, 11(3), 105-125.

Barnard, C. (1938). The functions of the executive. Cambridge, Mass: Harvard University Press. 
Barney, J. B. (1997). Gaining and sustaining competitive advantage. Reading, Mass: Addison-Wesley Publishing Company.

Bourgeois, L. (1981). On the measurement of organizational slack. Academy of Management Review, $6(1), 29-39$.

Bowen, F. (2002). Organizational slack and corporate greening: broadening the debate. British Journal of Management, 13(4), 305-316.

Bowman, C., \& Ambrosini, V. (2000). Value creation versus value capture: towards a coherent definition of value in strategy. British Journal of Management, 11(1), 1-15.

Bunge, M. (1996). Finding philosophy in social science. Greater London, UK: Yale University Press.

Chandler, A. D. (1962). Strategy and structure. Cambridge, Mass: The M.I.T. Press.

Chandler, A. D. (1977). The visible hand. Cambridge, Mass: The Belknap Press of Harvard University Press.

Chandler, A. D. (1990). Scale and scope. Cambridge, Mass: The Belknap Press of Harvard University Press.

Cheng, J., \& Kesner, I. (1997). Organizational slack and response to environmental shifts: the impact of resource allocation patterns. Journal of Management, 23(1), 1-18.

Collins, J. (2001). Good to great. New York, NY: HarperCollins Publishers.

Collins, J. C., \& Porras, J. I. (1994). Built to last: successful habits of visionary companies. New York: Harper Business.

Cyert, R., \& March, J. (1963). A behavioral theory of the firm. Englewood Cliffs, NJ: Prentice-Hall.

Daily, C., Dalton, D., \& Cannella, A. (2003). Corporate governance: decades of dialogue and data. Academy of Management Review, 28(3), 371-382.

Doty, D., \& Glick, W. (1994). Typologies as a unique form of theory building: toward improved understanding and modeling. Academy of Management Review, 19(2), 230-251.

Eisenhardt, K. (1989). Building theories form case study research. Academy of Management Review, 14(4), 532-550.

Eisenhardt, K., \& Martin J. (2000). Dynamic capabilities: what are they? Strategic Management Journal, 21(10/11), 1105-1121.

Fleck, D. L. (2001). The dynamics of corporate growth. Doctoral thesis, Faculty of Management, McGill University, Montreal, Canada.

Galbraith, J. (1973). Designing complex organizations. Reading, Mass: Addison-Wesley Publishing Company.

Gomes, R., \& Gomes, L. (2007). Proposing a theoretical framework to investigate the relationship between an organization and its environment. Revista de Administração Contemporânea, 11(1), 75-95.

Helfat, C. E., Finkelstein, S., Mitchell, W., Peteraf, M., Singh, H., Teece, D. J., \& Winter, S. G. (2007). Dynamic capabilities: understanding strategic change in organizations. Malden, MA; Garsington Road, Oxford; Carlton Vic, Australia: Blackwell Publishing.

Jensen, M. C., \& Meckling, W. H. (1976). Theory of the firm: managerial behavior, agency costs and 
ownership structure. Journal of Financial Economics, 3(4), 305-360.

Kiser, E., \& Hechter, M. (1991). The role of general theory in comparative-historical sociology. American Journal of Sociology, 97(1), 1-30.

Kocka, J. (1990). In scale and scope: a review colloquium. Business History Review, 64(4), 690-735.

Lawrence, P. R., \& Lorsch, J. W. (1967). Organization and environment. Boston, MA: Division of Research, Graduate School of Business Administration, Harvard University Publishing.

Lepak, D., Smith, K., \& Taylor, M. (2007). Value creation and value capture: a multilevel perspective. Academy of Management Review, 32(1), 180-194.

Matten, D., \& Moon, J. (2008). "Implicit" and "explicit" CSR. Academy of Management Review, $33(2), 404-424$.

Mellahi, K., \& Wilkinson, A. (2004). Organizational failure: a critique of recent research and a proposed integrative framework. International Journal of Management Reviews, 5-6(1), 21-41.

Meyer, M., \& Zucker, L. (1989). Permanently failing organizations. Thousand Oaks, CA: Sage Publications.

Miller, D. (1999). Notes on the study of configurations. Management International Review, 39(Special Issue), 27-39.

Miller, D., \& Friesen, P. H. (1977). Strategy-making in context: ten empirical archetypes. Journal of Management Studies, 14(3), 253-280.

Miller, D., \& Friesen, P. H. (1978). Archetypes of strategy formulation. Management Science, 24(9), 921-933.

Miller, D., \& Friesen. P. H. (1982). The longitudinal analysis of organizations: a methodological perspective. Management Science, 28(9), 1013-1034.

Miller, D., \& Friesen, P. H. (1984). Organizations: a quantum view. Englewood Cliffs, NJ: PrenticeHall.

Mintzberg, H. (1979). The structuring of organizations. Englewood Cliffs, NJ: Prentice-Hall.

Mintzberg, H., \& Waters, J. A. (1982). Tracking strategy in an entrepreneurial firm. Academy of Management Journal, 25(3), 465-499.

Mitchell, B. R. (1998). International historical statistics. New York, NY: Stockton Press.

Mohr, L. B. (1982). Explaining organizational behavior: the limits and possibilities of theory and research. San Francisco, CA: Jossey-Bass Inc., Publishers.

Moody's Investors Service. (1917-1995). Moody's industrial manual. New York, NY: Author.

Oliver, C. (1991). Strategic responses to institutional processes. Academy of Management Review, 16(1), 145-179.

Orton, J., \& Weick, K. (1990). Loosely coupled systems: a reconceptualization. Academy of Management Review, 15(2), 203-223.

Page, S. (2007). Making the difference: applying a logic of diversity. Academy of Management Perspectives, 21(4), 6-20.

Penrose, E. T. (1952). Biological analogies in the theory of the firm. American Economic Review, 
42(5), 804-819.

Penrose, E. T. (1980). The theory of the growth of the firm. White Plains, NY: M. E. Sharpe, Inc.

Peters, T., \& Waterman, R. (1982). In search of excellence. New York, NY: Harper \& Row.

Porter, M. E. (1980). Competitive strategy: techniques for analyzing industries and competitors. New York, NY: Free Press.

Porter, M. E. (1987). From competitive advantage to corporate strategy. Harvard Business Review, 65(3), 43-59.

Scherer, F. (1990) In scale and scope: a review colloquium. Business History Review, 64(4), 690-735.

Selznick, P. (1957). Leadership in administration. New York: Harper \& Row, Publishers.

Sidhu, J., Volberda, H., \& Commandeur, H. (2004). Exploring exploration orientation and its determinants: some empirical evidence. Journal of Management Studies, 41(6), 913-932.

Stickland, F. (1998). The dynamics of change. New York: Routledge.

Teece, D., Pisano, G., \& Shuen, A. (1997). Dynamic capabilities and strategic management. Strategic Management Journal, 18(7), 509-533.

Tushman, M., \& O'Reilly, C. (1996). Ambidextrous organizations: managing evolutionary and revolutionary change. California Management Review, 38(4), 8-30.

Weber, R. (1990). Basic content analysis. Thousand Oaks, CA: Sage Publications.

Weitzel, W., \& Jonsson, E. (1989). Decline in organizations: a literature integration and extension. Administrative Science Quarterly, 34(1), 91-109.

Whetten, D. (1980). Organizational decline: a neglected topic in organizational science. Academy of Management Review, 5(4), 577-588.

Whetten, D. (1987). Organizational growth and decline processes. Annual Review of Sociology, 13, $335-358$.

Winter, S. G. (2003). Understanding dynamic capabilities. Strategic Management Journal, 24(10), 991-995.

Yin, R. (1989). Case study research: design and methods. Thousand Oaks, CA: Sage Publication. 